\title{
Online Marketing Counseling and Assistance for MSMEs Dakota Convection
}

\author{
Anita Primastiwia), Desy Tri Inayah, Diki Sandi Andrian,'Sri Indah Ergina, Indra \\ Pratama, and Agung Sulistio
}

\author{
Sarjanawiyata Tamansiswa Yogyakarta University, Yogyakarta, Indonesia \\ a)Corresponding author: anita.primas@ustjogja.ac.id
}

\begin{abstract}
Sleman Regency is one of the regencies located in the Special Region of Yogyakarta Province, the beauty and natural wealth that is served even attracts the attention of many tourists, both local and international. In addition to the beautiful natural panorama, Sleman Regency also has many MSME actors so that it really supports the completeness of tourism in Sleman Regency, but due to the Covid-19 pandemic that has hit almost all countries, the tourism and MSME sectors have paralyzed so that a new life transition is needed, one of which is change the marketing of MSME products from offline to online. The presence of the community service team at Bachelorwiyata Tamansiswa University aims to foster the spirit of MSME actors by providing online marketing counseling and assistance to MSME actors. This activity consisted of socialization, counseling and training on online marketing which took place on Tuesday, September 15 , 2020. In general, most of the employees at Dakota Convection were enthusiastic to further promote online product marketing through the media website, Instagram, Facebook, and various marketplaces. .
\end{abstract}

Key words: Entrepreneurial spirit, MSMEs, marketing, and online

\section{INTRODUCTION}

Micro, Small and Medium Enterprises (MSMEs) are an important part of a country's economy, especially in an area, Indonesia is no exception (Wibowo et al., 2015). Economic development through the MSME sector has a positive impact on the Indonesian economy, besides that the development of the MSME sector can have a positive impact on the community in the form of encouragement and motivation for entrepreneurship. According to Wibowo et al. (2015) the development of the Micro, Small and Medium Enterprises (MSME) sector gives its own meaning to efforts to increase economic growth and in an effort to suppress a country's poverty rate (Wibowo et al., 2015). The existence of COVID-19 and after it was declared a pandemic in Indonesia, there were many sectors that were affected, one of which was the economic sector, both the domestic and global economy (Syamsudin, 2020). To overcome all this, of course, it is necessary to change the pattern of marketing strategies so that with current conditions remains a profitable opportunity so that it can survive in the in the middle of this pandemic (Yuliantari et al., 2021). The business sector most affected by the Covid-19 pandemic is the MSME sector, as a result of the Covid-19 pandemic, all activities carried out offline are multiplied into online so that MSME actors are required to change marketing methods that previously focused on offline marketing to online marketing. The implementation of ECommerce in running electronic commerce consists of technical and non-technical aspects. The technical aspect is the reliability aspect of electronic technology as the core and its supporting tools in its relationship as a commercial media. Technical aspects include components of hardware (hardware) and software (software) that build: web site, data communication network, data communication protocol, user interface (user interface) (Pelipa \& Marganingsih, 2020).

The transition from offline marketing to online marketing is not easy for all MSME actors, one of the MSME actors who are experiencing difficulties is Dakota Convection, from the results of observations made by the community service survey team at the University of Sarjanawiyata Tamansiswa showing that Dakota Convection has done online marketing, but it is still lacking. 
orderly and unscheduled, this condition shows that marketing employees still need training on online marketing. The problems faced by Dakota Convection employees related to online marketing are as follows:

a. It is still necessary to add continuous insight into the technology used in marketing MSME products online.

b. Lack of understanding of online marketing in an orderly and regular manner by marketing employees at Dakota Convection.

This community service activity aims to assist Dakota Convection employees in carrying out online product marketing and sustainability in the long term. Dakota Convection employees who do not fully understand the implementation of online marketing properly are expected to be able to carry out marketing of MSME products online and sustainably to the fullest. The mentoring activity provided to Dakota Konvection employees is in the form of providing counseling about marketing MSME products online through social media, websites and e-commerce.

\section{METHOD}

This community service activity was carried out in Dakota Convection which is located in Kadirojo II Hamlet, Purwomatani Village, Kalasan District, Sleman Regency, Yogyakarta Special Region. The process of implementing this activity program is carried out in four stages, namely:

1. Preparation stage

In the preparation activities, a team consisting of 5 people, that is Anita Primastiwi, SE., M.Sc., Desy Tri Inayah, M.Pd., Diki Sandi Andrian, Indra Pratama, and Sri Indah Ergina, conducted an initial survey in the Kadirojo II hamlet. to identify the potential of MSMEs that exist in the Kadirojo II Hamlet, the team conducted interviews, and observations to identify and identify the potential that exists in the Kadirojo II Hamlet. The preparatory stage is carried out in August 2020.

2. Stages of implementing activities

The training was carried out in two periods, each divided into 3 activity sessions. The first period was emphasized on the socialization and introduction of business and online marketing. The second period emphasized on online monitoring and evaluation of activities that have been carried out by Dakota Convection employees. Direct implementation activities were carried out on Tuesday, September 15, 2020.

3. Evaluation

Evaluation activities were carried out by conducting interviews and observations of employees in Dakota Convection and the community of Kadirojo II Hamlet, Purwomartani Village, Kalasan District, Sleman Regency, Special Region of Yogyakarta. The evaluation process is carried out online via telephone, WhatsApp, and other social media. After the data is collected, it can be seen the obstacles that arise in the online marketing process, both those that arise from within and outside Dakota Convection.

4. Report generation

The preparation of activity reports is carried out in 3 stages, namely:

1) Preparation of reports on the results that have been achieved during the program, preparation of reports on training activities made after the implementation of training activities for employees of Dakota Convection.

2) Revision of the report, the revision of the report was carried out to correct errors in several parts of the initial report on the implementation of activities in Dakota Convection.

3) The final report is made after the revision process, so that a final report is produced on the implementation of the training program in Dakota Convection. 


\section{RESULTS}

The results achieved are in the form of capacity development in the form of soft skills for Dakota Convection employees who are located at Kadirojo II Hamlet, Purwomartani Village, Kalasan District, Sleman Regency, Special Region of Yogyakarta in running, creating, designing businesses and marketing by utilizing technological developments.

\section{DISCUSSION}

This community service activity was initiated by conducting a survey by the team to the location by meeting with the community to identify the activities of the surrounding community, the potential and constraints of the community in doing business. After the team got the data, the team began to formulate solutions for solving the problem, the formulation was carried out by the team by inviting the owner of Dakota Convection. The formulation of the event resulted in a series of activities that were divided into two periods, the first period was to grow the introduction of online business and marketing as well as the provision of technical skills for Dakota Convection employees as the people of the Kadirojo II Hamlet, Purwomartani Village, Kalasan District, Sleman Regency, Yogyakarta Special Region, while the second period is used for monitoring and evaluating business activities and online marketing carried out by Dakota Convection as a community of SMEs in the Kadirojo II hamlet, Purwomartani Village, Kalasan District, Sleman Regency, Yogyakarta Special Region if there are obstacles or problems in entrepreneurship.

\section{CONCLUSIONS AND RECOMMENDATIONS}

The community service team of the Faculty of Economics, Sarjanawiyata Tamansiswa University, Yogyakarta, has provided a concept about designing schedules and making designs for online marketing facilities to Dakota Convection employees who are located at Kadirojo II Hamlet, Purwomartani Village, Kalasan District, Sleman Regency, Special Region of Yogyakarta. The results achieved from this program are in the form of capacity development in the form of soft skills for Dakota Convection employees. The community service team of the Faculty of Economics, Sarjanawiyata Tamansiswa University also provides online assistance to Dakota Convection in the implementation of online product marketing in a sustainable manner. The pessimism of Dakota Convection's employees towards online marketing is an obstacle in the process of sustainability of online product marketing. With continuous assistance, it is hoped that Dakota Convection can continue marketing activities online, in addition to increasing sales targets, online marketing also has a positive impact because it has followed the development of increasingly developing technology and follows business competition in the digital era. This is in line with research conducted by Prasetio et al., (2018) that the implementation of ICT (Information Communication Technology) in the MSME sector helps business processes so as to increase MSME productivity and assist MSME product marketing processes broadly.

\section{ACKNOWLEDGMENTS}

Thanks are given to:

1. God.

2. LP3M Universitas Sarjanawiaya Tamansiswa Yogyakarta which has provided the opportunity and funded this community service activity so that the activity can run smoothly.

3. The owner and all employees of Dakota Convection having their address at Kadirojo II Hamlet, Purwomartani Village, Kalasan District, Sleman Regency, Special Region of Yogyakarta. 


\section{REFERENCES}

Ahmadi, Candra \& Dadang Hermawan, (2013). E-Business \& E-commerce, Edisi 5, Andi Offset Buchori, A.(2016). Kewirausahaan. In Alfabeta, Bandung. Alfabeta.

Krismiaji. (2015). Akuntansi Manajemen. UPP STIM YKPN.

Pelipa, E. D., \& Marganingsih, A. (2020). Pelatihan E-Commerce Untuk Usaha Mikro Kecil Menengah Di Kota Sintang. Jurnal Pengabdian Masyarakat Khatulistiwa, 3(2), 94-105. https://doi.org/10.31932/jpmk.v3i2.900

Prasetio, R. T., Mubarok, A., Ramdhani, Y., Junianto, E., Rismayadi, A. A., Anshori, I. F., Hidayatulloh, S., \& Topiq, S. (2018). Upaya Peningkatan Produktivitas UMKM Melalui Implementasi ICT pada Look At Hijab Bandung. Jurnal Pengabdian Kepada Masyarakat, 1(1), 104-111.

Suliyanto. (2010). Studi Kelayakan Bisnis, Yogyakarta. Andi

Suryana. (2014). Kewirausahaan, Jakarta. Salemba Empat

Syamsudin, M. (2020). Dampak Pandemi Covid-19 terhadap UMKM di Indonesia. NUONLINE. https://www.nu.or.id/post/read/123247/dampak-pandemi-covid-19-terhadap-umkm-diindonesia

Swastha, B. (2010). Manajemen Penjualan: Pelaksanaan Penjualan. BPFE-Yogyakarta.

Wibowo, D. H., Arifin, Z., \& Sunarti. (2015). Analisis Strategi Pemasaran Untuk Meningkatkan Daya Saing UMKM (Studi pada Batik Diajeng Solo). Jurnal Administrasi Bisnis (JAB), 29(1), 59-66.

Yuliantari, K., Hilawu, S., Lestiowati, R., \& Lahat, M. A. (2021). Jurnal Abdimas Ekonomi dan Bisnis UMKM Go Online Upaya Lawan Covid-19 Kelompok Ibu-ibu PKK Kelurahan Lubang Buaya Jakarta Timur Jurnal Abdimas Ekonomi dan Bisnis. 1(1), 44-50. 


\section{APPENDIX}

Table 1. Schedule of activities

\begin{tabular}{|c|c|c|c|c|c|c|}
\hline \multirow[b]{2}{*}{ Activities } & \multicolumn{6}{|c|}{2020} \\
\hline & August & $\begin{array}{c}\text { September } \\
\text { week } 1\end{array}$ & $\begin{array}{c}\text { September } \\
\text { week } 2\end{array}$ & $\begin{array}{c}\text { September } \\
\text { week } 3\end{array}$ & $\begin{array}{c}\text { September } \\
\text { week } 4\end{array}$ & October \\
\hline $\begin{array}{l}\text { Preparation } \\
\text { Implementatio } \\
\text { of activities }\end{array}$ & & & & & & \\
\hline $\begin{array}{c}\text { Evaluation } \\
\text { Report } \\
\text { generation }\end{array}$ & & & & & & \\
\hline
\end{tabular}

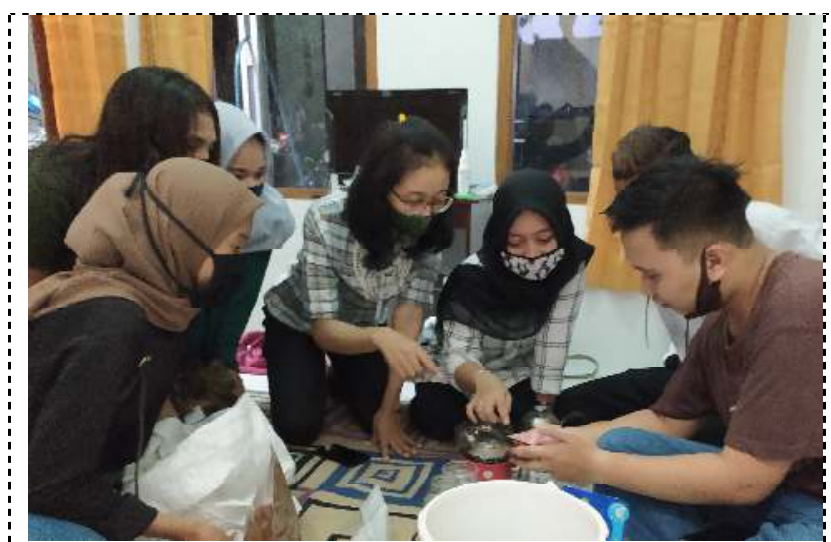

Figure 1. Delivery of material by Anita Primastiwi SE., M.Sc. and Desy Tri Inayah, M.Pd.

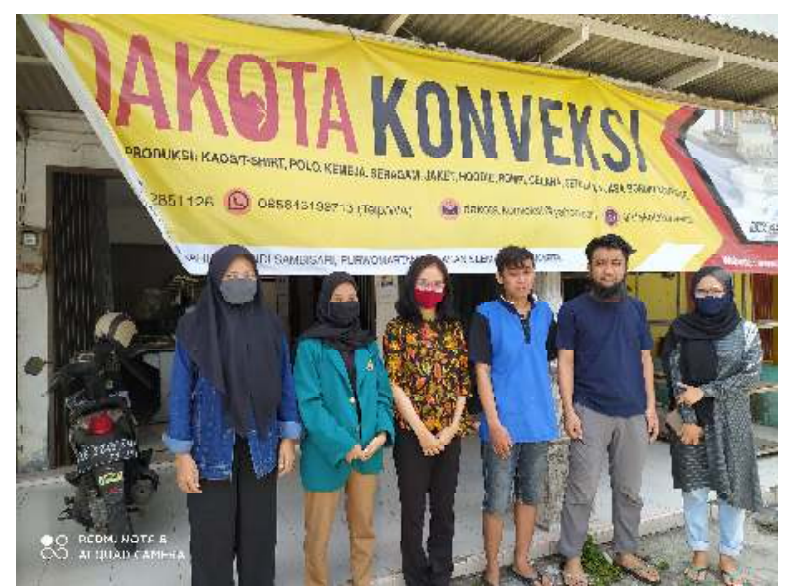

Figure 3. The closing of the event (photo with the manager of Dakota Convection)

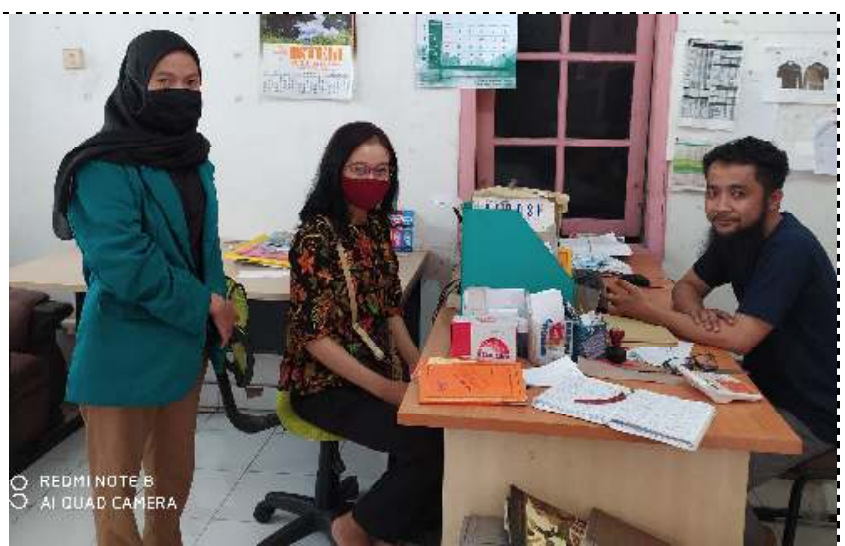

Figure 2. Discussion with the manager of Dakota Convection

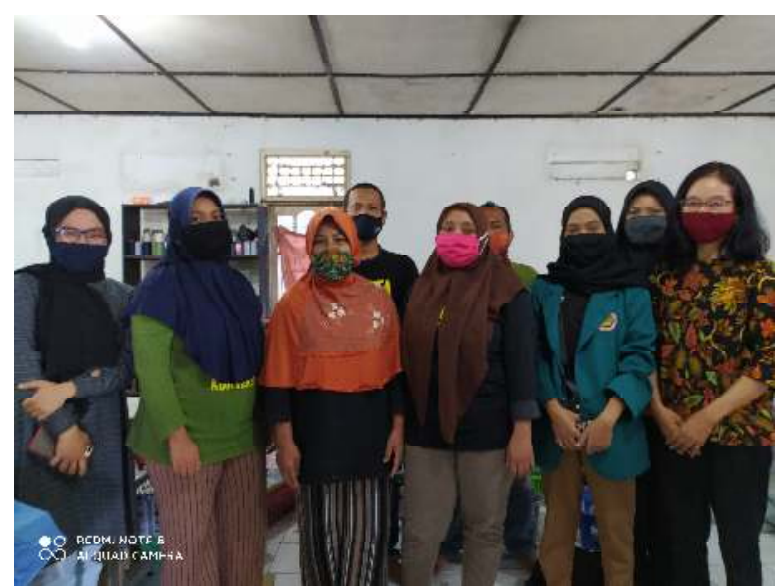

Figure 4. The closing of the event (photo with the employee of Dakota Convection) 